\title{
Census of Brazilian Merganser Mergus octosetaceus in the region of Serra da Canastra National Park, Brazil, with discussion of its threats and conservation
}

\author{
IVANA REIS LAMAS
}

\section{Summary}

The biggest and best-known population of Brazilian Merganser Mergus octosetaceus occurs in the region of Serra da Canastra National Park, Minas Gerais, Brazil. However, prior to our study it had been recorded in only six sites in the park and its buffer zone. In 2001 and 2002 we surveyed the region to confirm the occurrence of the Brazilian Merganser in different areas within and outside the park. Samples were taken by walking along the banks of the watercourses, using tape-recording playback. We sampled 49 stretches of streams, and observed Brazilian Mergansers in nine localities, totalling 29 sightings. Taking into consideration the reports by biologists who participated in the fieldwork for the review of the park's management plan, the guaranteed reports of the occurrence of the species from local people, and the sites where its occurrence is judged to be very likely, we believe there are at least 81 individuals in the areas sampled. We point out that the absence of records in an area does not mean the absence of the species. Indeed, the presence of the Brazilian Merganser was confirmed, after the end of our field studies, in some stretches where we indicated its occurrence as very likely but had failed to detect it during the sampling. All anthropogenic activities that influence the quality and integrity of the rivers and their banks are a potential threat to Mergus octosetaceus. Efforts to preserve the species entail the conservation of its habitats, which comprise important watercourses and the surrounding natural vegetation.

\section{Introduction}

The Brazilian Merganser Mergus octosetaceus is considered a Critically Endangered species at the global level according to the IUCN (Hilton-Taylor 2000), and in Brazil (MMA 2003). It is estimated that fewer than 250 survive in the wild (BirdLife International 2000). Its known area of distribution included the mid-south of Brazil (the states of Goiás, Minas Gerais, Mato Grosso do Sul, São Paulo, Rio de Janeiro, Paraná and Santa Catarina) and parts of Paraguay and Argentina (Antas 1996, Pacheco and Fonseca 1999). A few recent sightings confirm this species still survives in Argentina (Giraudo and Povedano 2003). In Paraguay, the Brazilian Merganser is now regarded as locally extinct (Fragano and Clay 2003).

In recent decades, Brazilian Merganser has been recorded at a few sites in Brazil, usually in strictly protected areas such as the national parks of Chapada dos Veadeiros, Emas and Serra da Canastra (Yamashita and Valle 1990, Collar et al. 1992, Silveira and Bartmann 2001). There are recent sight reports from western Bahia (Pineschi and 
Yamashita 1999) and from the Jalapão State Park, Tocantins (Braz et al. 2003), thus enlarging its original area of distribution. The largest population of the species inhabits the Serra da Canastra National Park and surrounding area (Bartmann 1988, Silveira and Bartmann 2001).

The Brazilian Merganser occurs naturally in low densities and the fact that it is a rare species is not exclusively a result of threats imposed by man. In 1901 it was already described as very rare (Bertoni 1901 in Partridge 1956) and, until quite recently, there existed little information on the biology of the species (Bartmann 1988, Silveira and Bartmann 2001, Lamas and Santos 2004).

The species is known to inhabit clean rivers and streams, with rapids bordered by forests, in sparsely populated areas. It is a shy bird and is quite difficult to see in the wild (Partridge 1956, Bartmann 1988, Collar et al. 1992, Silveira and Bartmann 2001). Yamashita and Valle (1990) argued that the main limiting factors to its distribution are the structure of the river, with clear rapids, rather than the vegetation on its banks. Lamas and Santos (2004) recorded a nest in a rock crevice, confirming that Brazilian Merganser does not necessarily depend upon riparian forests for reproduction, as was once believed. It most likely dwells the entire year in the same area and the size of its territories should be related to the number of river rapids, edgewaters, water speed, fish abundance, conservation degree of riparian vegetation, and other factors that determine the quality of territories.

The development of agriculture, the degradation of river basins and soil erosion have seriously affected watercourses which would otherwise be suitable for Brazilian Merganser (Partridge 1956, Bartmann 1988, Collar et al. 1992). As it is highly vulnerable to habitat alterations and human pressure, Bartmann (1988) suggested that the species' survival would only be guaranteed within strictly protected areas. Nevertheless, it persists in some streams outside the boundaries of Serra da Canastra National Park (Silveira and Bartmann 2001).

In parallel with a review of the management plan for Serra da Canastra National Park, a survey was developed in an attempt to confirm the occurrence of Brazilian Merganser in different areas within and outside the park. Prior to our study, Brazilian Merganser had been recorded in three sites in the park as well as in three other locations in its buffer zone (Silveira and Bartmann 2001).

\section{Area surveyed and procedures}

The Serra da Canastra National Park, which became a nationally protected area encompassing 200,000 ha in 1972, is located in south-west Minas Gerais, Brazil, and comprises parts of the municipalities of São Roque de Minas, Sacramento, Vargem Bonita, São João Batista do Glória, Capitólio and Delfinópolis. However, only 71,500 ha of the park have the land tenure regulated. Criss-crossed by an extensive and complex drainage system, Serra da Canastra National Park includes part of the headwaters of two important Brazilian river basins — São Francisco and Paraná — in an area predominantly covered by cerrado (Brazilian savanna).

Transects were sampled on a monthly basis from July 2001 to July 2002. On average, data were collected 5 days per month. The watercourses sampled were chosen from IBGE (Brazilian Institute of Geography and Statistics) topographic maps. Through analysis of these maps, we identified the streams that apparently showed a significant volume of water, and seemed to hold potential for occurrence of the 
Brazilian Merganser. Watercourses were reached by car, on horseback or on foot. As we travelled to the destinations selected, we opportunistically assessed other watercourses along the way, examining feasibility for sampling and likelihood of the occurrence of the species.

Several rural properties were visited both in order to obtain information on the best access and roads and to raise awareness concerning the potential presence of the merganser. When the person interviewed accurately described the external morphological characteristics of the species without any help, we viewed that piece of information as reliable and included it in this analysis.

Samples were taken by walking along the banks of watercourses. Depending on the local topography, we sometimes had to wade in the water or briefly walk away from the banks. Playback was often used. The tape recordings were kindly lent by Professor Dr Luiz A. P. Gonzaga of the Universidade Federal do Rio de Janeiro. We used Panasonic RQ-L1o tape players and Sony SRS-121 speakers. The frequency of use of the playback increased as it became more difficult to view long stretches of rivers and near noisy rapids or waterfalls. With calm waters and without strong winds, the sound played by the speakers was audible up to $150 \mathrm{~m}$. By then, we believed that both males and females always responded to playback in defence of their territories.

At intervals of approximately 1,000 m along transects, a $30 \mathrm{~m}$ stretch of river was examined to characterize the habitat following a proforma that assessed the riparian vegetation and the structure of the river and its waters. Thus, the number of points varied according to the length of the transect, which in turn was limited by how difficult it was to walk along the banks. A minimum of three points were sampled per transect, which corresponded to a $2 \mathrm{~km}$ stretch, with a maximum of six points corresponding to a $5 \mathrm{~km}$ stretch. Most commonly, however, five points, corresponding to $4 \mathrm{~km}$ of the river, were sampled. GPS was used to mark river curves in such a manner as to make it possible to estimate $1,000 \mathrm{~m}$ intervals between points based on the course of the river and not on the minimum distance between points.

The streams sampled, according to the distances travelled and the number of the points characterized, are presented as follows:

- $2 \mathrm{~km}$ (three points): Santo Antônio (Fundão farm), Boa Vista, Parida, Picada, Fumal (Turvo basin), Cachoeira, Coelhos (high part), Coelhos (low part), Matinha (low part), Matinha (high part), Engano, Quebra-Anzol, Usina and Posses (low part), and São Francisco (high Casca D'Anta).

- $3 \mathrm{~km}$ (four points): Rolinhos (low part), Capetinga, Rolinhos (high part), Pombos, Quilombo, Prata, and Posses (high part).

- $4 \mathrm{~km}$ (five points): Grande (RPPN Cerradão), Joana, Fumal, Cochos (Casa de Pedra), Fazenda, Pedras, Grande, Bom Jesus, Formiga, Bateias, Turvo, Grota Feia, Capivaras, Lavras and Pinheiro, São Francisco (low part), São Francisco (headwaters), Araguari (high part), Araguari (low part), Araguari (middle), Samburá, Santo Antônio (South), and Peixe.

- $5 \mathrm{~km}$ (six points): Claro, Cabeceira, Babilônia, and Santo Antônio (North).

The long, linear territories of the Brazilian Merganser, varying from 4 to $12 \mathrm{~km}$ in length (Silveira and Bartmann 2001), required an analysis of environmental characteristics as a whole, with the goal of characterizing the entire stretch of river that was travelled as a sum of the variables evaluated at each point.

Statistical analyses were developed with some of the variables measured in order to characterize the habitat. The level of conservation of the watercourses was defined 
as high, medium or low, according to the conservation category most frequently observed at the sample points. Also, a stream was considered to have a low, medium or high pollution potential according to the frequency of pollution sources at the sample points. Similarly, watercourses were categorized according to the frequency of evidence of erosion and thus classified as either little or very eroded. Whenever the transparency of the water permitted, the occurrence of different types of substrates in the river bed was recorded: slate, bedrock, pebbles, gravel, sand, and silt. Based on the samples, the substrate was considered to be either present or absent for each watercourse. We did not interrupt the fieldwork because of weather conditions. The chi-square test (Zar 1984) was applied to test whether there was an association between the occurrence of the species and those variables. To test the relationship between the presence of the species and the stream order (Strahler 1957), logistic regression was used (Hosmer and Lemeshow 1989).

\section{Results}

Forty-nine stretches of streams were sampled, which is equivalent to approximately $165 \mathrm{~km}$ of observation on foot along the rivers. Such an undertaking is roughly equivalent to 165 hours of observation, because $1 \mathrm{~km}$ was covered in an average of about 1 hour. The São Francisco and Araguari rivers were sampled at three distinct stretches. In the Coelho, Matinha, Posses, Cochos and Rolinhos streams, two samples were taken at different stretches.

Sampled areas, with and without the confirmation of the presence of Brazilian Merganser, are shown in Fig. 1. We confirmed the presence of Brazilian Mergansers

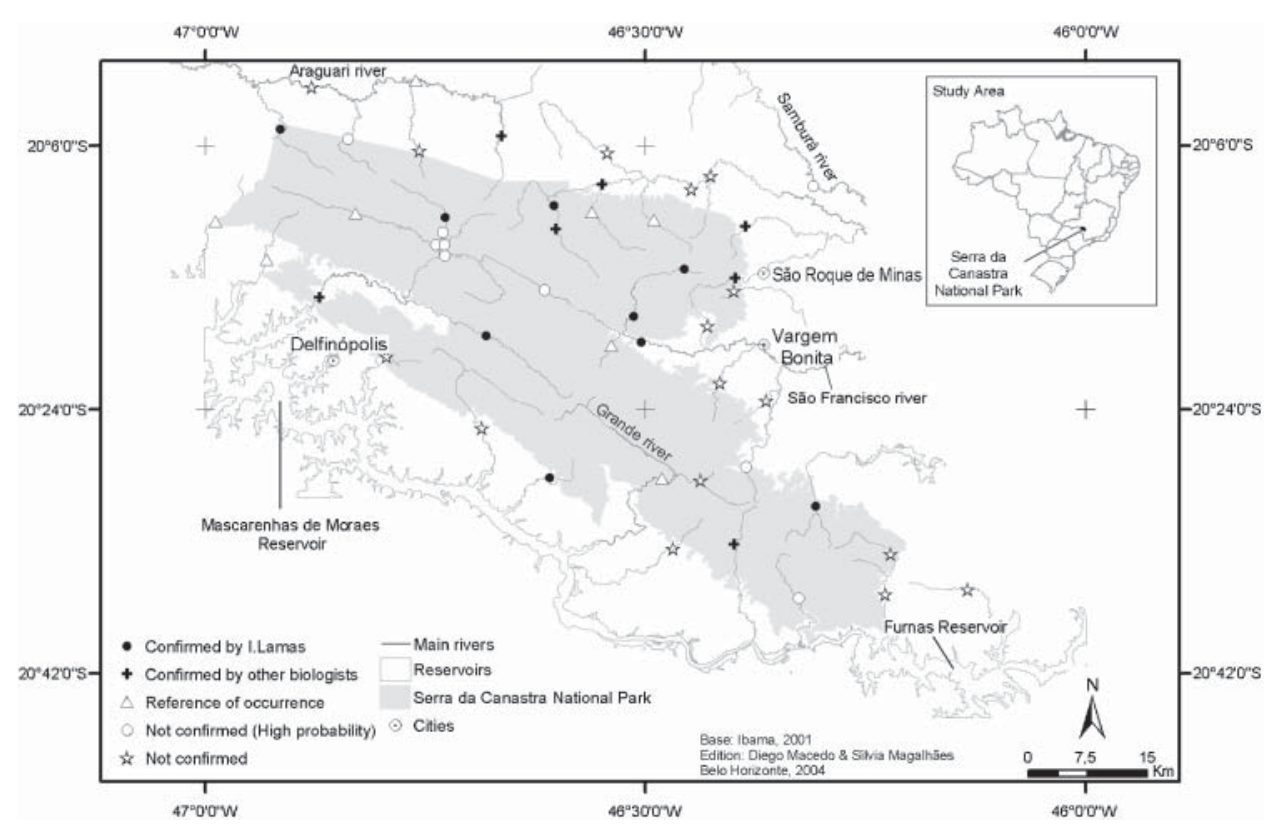

Figure 1. Stretches of sampled rivers indicating confirmed presence (or lack thereof) of Brazilian Mergansers in the Serra da Canastra National Park region. 
in nine localities, totalling 29 individuals, 13 of which were offspring. In addition to these, other biologists who participated in the fieldwork specifically to review the park's management plan confirmed the merganser at seven localities, recording 18 individuals, 6 of which were probably offspring.

Eight other creeks, where reliable information on the presence of the species was obtained from the local people, augmented our results. We thus believe we located at least 24 different territories of Brazilian Merganser in the area studied, supporting approximately 47 individuals (28 adults and 19 young). The addition of, conservatively, one pair at each watercourse where we obtained evidence of an active territory would result in 16 more adults.

In at least nine surveyed stretches where the Brazilian Merganser was not confirmed, its occurrence is very likely due to the structural characteristics of the watercourses. If one pair were assumed to inhabit each of those stretches, it would add a further 18 individuals, bringing the total to 81 individuals, considering only the areas sampled.

No statistically meaningful relationships were found between the presence of the species and the environmental variables measured: level of conservation, pollution, erosion, river bed substrate, and the stream order.

\section{Discussion}

Brazilian Merganser is a non-migratory species, which does not abandon the watercourses where it sets up its territory (Partridge 1956, Silveira and Bartmann 2001). Indeed, in all flights observed, the mergansers followed the stream course faithfully, sometimes close to the surface, sometimes slightly above the vegetation (about $10 \mathrm{~m}$ high). Our analyses are based on the assumption that the birds' movements are highly restricted to their territories. Nonetheless, the hypothesis that they do not travel between watercourses has not been tested and therefore cannot be discarded.

Visual distinction among individuals along different stretches of a single sub-basin was difficult and sometimes was based on assumption. In the São Francisco river, for instance, we know definitely that a pair inhabits the high part of the Casca D'Anta waterfall and another inhabits the lower part close to the town of São José do Barreiro, because a pair with two young ducklings was seen above the falls in the same month that we recorded another pair with six larger ducklings near São José do Barreiro. According to Silveira and Bartmann (2001), there is one more pair between these two sites along the São Francisco river. The territory of this pair must encompass the Cachoeirinha stream, where a reliable report of the frequent presence of Brazilian Mergansers was obtained. Still in the São Francisco river, three individuals were spotted flying approximately $5 \mathrm{~m}$ above the stream following the watercourse, close to the springs, in February 2002. Considering that the pair in the high part of Casca D'Anta was seen in January without any offspring and that the extent of river between the springs and the waterfall allows for the establishment of one more territory, we can suppose that this is a fourth pair, which was accompanied by a single, older offspring. Silveira and Bartmann (2001) observed that the young can stay in their parents' territory until nearly the next mating season.

We cannot categorically affirm, either, that the pair observed in the Santo Antônio stream on Fundão Farm is not the same one spotted in its high part, close to the Casa de Pedra, for the movement of the mergansers upstream and downstream of Fundão 
waterfall appears to be possible, since the waterfall is about $60 \mathrm{~m}$ in height. Nevertheless, knowing that its home range reaches on average as far as $9 \mathrm{~km}$ (Silveira and Bartmann 2001), we believe that the Santo Antônio stream could support two or more pairs.

We do not know yet whether the mergansers are capable of flying up and down the Rolinhos waterfall. Yet, due to the abrupt height difference (almost $300 \mathrm{~m}$ ), we think there is likely to be at least one territory above and another downstream from the waterfall. The pair observed in the Babilonia stream may be the same "pair 5 " registered by Silveira and Bartmann (2001) in the Posses stream.

During our fieldwork we believed that all Brazilian Mergansers, both male and female, promptly responded to tape-recording playback as soon as it was heard. We observed this on numerous occasions. Nevertheless, during a visit to one of the sites where a pair was observed, after the end of the field study, we witnessed a different behaviour. A lone bird was swimming apparently quietly in a stream. When we played the recording, it slowed down and retracted its neck. Always facing the direction where it heard the sound coming from, it withdrew slowly to the opposite side of the stream, close to a rock. It remained there with minimal movement for about 20 minutes, then finally slipped away downstream.

We have tried to find an interpretation for this behaviour, but we have no clear answer; it did not seem to us to be a type of nest protection behaviour (Lamas and Santos 2004). We speculate that the bird could have been an immature in search of a territory but not confident enough to defend it. This type of behaviour shows that the sighting of specimens is the most reliable way of confirming the presence of the species. Although playback is definitely very useful in censusing Brazilian Mergansers, we emphasize the importance of obtaining visual records in field studies.

The high number of watercourses is one of the most conspicuous characteristics of the region under study. It is difficult to estimate the percentage of the total drainage of the region we were able to census, but it was definitely a limited sampling. Surely other unvisited watercourses shelter additional territories of Brazilian Mergansers and the local population must be much higher. On several occasions the local inhabitants reported the presence of "small, dark and fierce ducks", very likely referring to the Brazilian Merganser. Such information, though, was not deemed reliable for want of a more accurate description of the external morphology of the birds.

The fact that we did not record the species at some sites certainly does not mean that birds were not there. Indeed, the presence of the Brazilian Merganser was confirmed, after the end of our field studies, in some stretches where we indicated its occurrence as very likely but had failed to detect it during sampling, such as the Samburá river (B. Garzon 2004, pers. comm.). This corroborates our inferences about the local population size.

At some sites, confirmation of the presence of the merganser will be more difficult. For instance, the region around the confluence of the Coelhos, Matinha, Posses and Pombos streams has abundant running water and is isolated from human activity, including tourism. Not even the park workers visit the area frequently. Several pairs of Brazilian Merganser are strongly suspected to live in that area.

In the effectively protected part of Serra da Canastra National Park (about 71,000 ha of land tenure already regulated), all watercourses, including the springs (except for the Posses stream, which rises outside the park's borders) are under strict protection. The current human influences in this region are restricted to deliberate 
land burning and tourism, in addition to the frequent vehicle traffic that uses the park's roadways to travel between towns and villages in the vicinity. Its crystal-clear waters, the structural characteristics, with riffles and pools of varied sizes and depth, and the abundance of healthy riparian vegetation are elements that undoubtedly provide high-quality habitat for Brazilian Merganser.

At the Chapadão da Babilonia (a park area with no regulated land tenure), the region of Delfinópolis, and in the park's buffer zone, environmental conditions vary a great deal and some streams in a highly conserved state are very close to others in an advanced stage of degradation.

The results of the analyses of the characteristics of preferential habitats show that, considering the manner in which habitats were evaluated, the presence of Brazilian Merganser does not show strict dependence on any of the parameters analysed. We do believe, however, that the species depends on several specific characteristics of the habitat. It was ascertained that Brazilian Merganser is able to withstand a certain degree of environmental degradation, as can be seen in the Formiga stream, where four individuals were observed $100 \mathrm{~m}$ above a rather degraded stretch. Nonetheless, it is not possible to infer how the level of degradation might affect territories and the merganser's basic behaviour. Other methods for habitat study must be adopted in search of relationships between the presence of the species and some environmental parameters, including the food supply.

Territory size must be heavily determined by such factors as the abundance of food. Fish make up the main food of the species (Partridge 1956). According to Fábio Vieira (2002, pers. comm.), the fish fauna in the park is characterized mostly by species that do not grow over $15 \mathrm{~cm}$ as adults. The most abundant species of fish were Astyanax scabripinnis, $A$. rivularis and Phalloceros caudimaculatus. In the effectively protected area of the park only four species were recorded: Astyanax rivularis, A. scabripinnis, Neoplecostomus aff. paranensis and Trichomycterus aff. brasiliensis.

The findings of this study lead us to the conclusion that the world population of Brazilian Merganser is much larger than the estimate of 250 individuals (BirdLife International 2000). After a year's study, a population of well over 80 individuals is estimated for the region of Serra da Canastra. However, its Critically Endangered status should be maintained, and actions geared towards the conservation of the species and its habitats must be prioritized.

\section{Threats to the Brazilian Merganser and its conservation in the Serra da Canastra National Park region}

Besides being a naturally rare species (Giraudo and Povedano 2003), Brazilian Merganser suffers several pressures that contribute to the decrease of its populations. In the region of Serra da Canastra National Park, the main threats are degradation and destruction of its habitats, mainly outside the park and in the park's unguarded area, as well as the intensification of ecotourism in the whole region. All the anthropogenic activities that influence the quality and integrity of the rivers and their banks are a potential threat to Brazilian Merganser.

Brazilian Merganser occurs mainly in watercourses with riffles, pools and waterfalls. Changes in the hydrological regime, mainly due to the implementation of hydroelectric power plants, turning former long stretches of rivers into reservoirs, are an extremely relevant factor in the species' population dynamics. The dams of Furnas 
and Mascarenhas de Moraes flooded several kilometres of flowing water, wiping out habitats that certainly held several territories. There are new such projects under way in the Serra da Canastra region and it is clear that changes in the hydrological regime continue to constitute an important threat. To date, the only record of a Brazilian Merganser in standing waters (Marconi Cerqueira Junior and Gabriel de Paula 2004, pers. comm. and pers. obs.) seems to be an occasional occurrence.

The destruction of riparian forests, though forbidden by law, is still a common practice in the region. We often observed, both on the banks and in the river, remains of deforestation. Degradation of the banks and erosion and silting of watercourses result from removal of riparian vegetation. On cattle-raising farms where riparian forest still survives, the cattle are allowed to enter the vegetation to access the watercourses, which leads to the destruction of the undergrowth and compaction of the soil. Rarely did we find fences stopping the cattle from gaining access to the riparian forest. This vegetation, besides safeguarding the watercourses from adjacent anthropogenic activities, provides an important measure of isolation for the mergansers.

Many of the mining companies in the region are clandestine and operate under no supervision whatsoever. Some springs and headwaters seem compromised by this mining activity. Frequent dynamiting and waste disposal on the hillsides cause further damage. We have observed the build-up of pieces of rock on the banks of the Quebra Anzol stream, which is also likely to be seen in other rivers. Rigorous inspections must be carried out in order to preserve the local water resources. Clandestine activity must be stopped and licences revoked in the park area and its buffer zone.

Domestic sewage, along with the pesticides used on pastures and crops, leaches into the drainage system and has become a major source of permanent pollution. Cultivation of crops sometimes extends as far as the river banks. The various roads that cross drainages also increase sediment transport to aquatic environments.

Tourism activities in the park of the type developed thus far do not seem to interfere significantly with the Brazilian Merganser's behaviour, given that a pair has been breeding successfully over the years in one of the most often visited areas in the park (Bartmann 1988, Silveira and Bartmann 2001, and personal observations). Nevertheless, there has been a significant increase in tourism, both in the park and in its vicinity. The ever-growing number of tourists who come looking for rivers and waterfalls could potentially interfere with the birds' behaviour; this should be monitored closely.

Another noteworthy but very poorly understood type of impact is the presence of exotic species of fish in the region. The Peacock Bass (Cichla sp.), along with other allochthonous species, was introduced into the reservoirs of Furnas and Mascarenhas de Moraes. The Peacock Bass is also very common in fish-and-pay ponds. Such predatory species have caused profound changes in the environments where they have been introduced, with the disadvantage that there are no effective processes to eradicate the species once it has settled in a host community (Fabio Vieira 2002, pers. comm.). Though the Peacock Bass prefers to inhabit mostly still-water environments, it is possible to find it in river stretches. Being an essentially fish-eating species, it may alter the dynamics of the native water communities as it becomes established. Small native fish make up the Brazilian Merganser's basic source of food and any factor interfering with the supply may have serious consequences for its populations.

Hunting does not seem to be a current threat to the Brazilian Merganser. We heard stories we could not substantiate that the species used to be hunted in the past. Some local inhabitants claimed that it is not advantageous to hunt the bird as it is difficult 
to approach and at the same time small and with very little meat. Yet, one has to take into account that the whole subject of "hunting" is mostly avoided by all and only rarely have we found someone willing to provide positive information.

In the Grande stream, downstream from the Cerradão waterfall, two dogs accompanied us throughout the stretch sampled. They seemed excited by the sound of the playback and would often go into the water on alert. Such behaviour indicated to us a possible agonistic interaction between dogs and the mergansers. The Dourado (Salminus maxillosus), one of the most voracious fish of high Paraná, is a potential enemy to young ducklings of any species (Partridge 1956). Studies are needed to ascertain interspecific interactions and their consequences for the region's Brazilian Merganser population.

The scarcity of information on the Brazilian Merganser's biology and behaviour makes it difficult to make decisions affecting the conservation and management of the species. Studies on reproduction, feeding behaviour, territories, intra- and interspecific interactions, and factors affecting the species must be encouraged. The Serra da Canastra National Park region is home to a relatively stable population, which could give concrete and generalizable answers to the question of the species' conservation. Research involving the marking of individuals, preferably with the use of radio transmitters, for confirmation of the home range, and daily and seasonal movements, is essential to accurate estimates of the size and dynamics of the population in the park region.

It is also vital to promote an awareness-raising campaign among local people on the importance of the species. Most inhabitants do not know the Brazilian Merganser. The community of São Roque de Minas and its vicinity is more aware of the occurrence of this species, most probably due to the tourism of birdwatchers who regard the Brazilian Merganser as one of the highlights of the park and to the relatively common presence of researchers on the lookout for the species. Thus, divulging the importance of the species to the community, and demonstrating that its presence in the region is a valuable feature and something to be proud of, could get people involved and committed in the search for, and application of, beneficial actions for its conservation. It is worth repeating that the conservation of the species necessarily depends on measures involving the recuperation and conservation of riparian forests, watercourses, and their springs and banks. The awareness-raising work would then be geared towards the rescue of fundamental values of land use and environmental conservation. The creation of private reserves would complement conservation needs, thus helping to maintain habitats favourable for Brazilian Mergansers.

\section{Acknowledgements}

I thank Sônia E. Rigueira, Jean Pierre Santos, Lívia Lins, Carlos Eduardo A. Carvalho, Lemuel O. Leite, Rosilene A. Ferreira, Mauro Guimarães, Luiz Fábio Silveira, Wolf Bartmann, Luiz Gonzaga, José Fernando Pacheco, Roberto Murta and Baz Hughes; the Park workers Delmo H. Alves, Amadeo P. dos Santos and Adaniel D. Matos; the biologists Dante Buzzetti, Fábio Vieira, Leonardo Viana, Lúcio Bedê, Renato Feio, Roberto Antonelli Filho, Rogério de Paula and Rosana Romero. Thank also go to Diego Macedo, Silvia Magalhães, Edmar Moretti, Alexandre Godinho, Adriano Paglia, Yuri Leite, Marco Antônio Andrade, and to the many inhabitants of the region, who supplied us with much-needed information. I am also grateful to Dr Bret Whitney for his very helpful comments on the manuscript. 


\section{References}

Antas, P. T. Z. (1996) The Brazilian Merganser (Mergus octosetaceus), the most threatened duck in South America. Game Wildfl. 13: 799-800.

Bartmann, W. (1988) New observations on the Brazilian Merganser. Wildfowl 39: 7-14.

BirdLife International (2000) Threatened birds of the world. Barcelona and Cambridge, U.K.: Lynx Edicions and BirdLife International.

Braz, V. S., Abreu, T. L. S., Lopes, L. E., Leite, L. O., França, F. G. R., Vasconcellos, M. M. and Balbino, S. F. (2003) Brazilian Merganser Mergus octosetaceus discovered in Jalapão State Park, Tocantins, Brazil. Cotinga 20: 68-71.

Collar, N. J., Gonzaga, L. P., Krabbe, N., Madroño Nieto, A., Naranjo, L. G., Parker III T. A. and Wege, D. C. (1992) Threatened birds of the Americas: the ICBP/IUCN red data book. Washington, DC: Smithsonian Institution Press and International Council for Bird Preservation.

Fragano, F. and Clay, R. (2003) Biodiversity status of the Interior Atlantic Forest of Paraguay. Chapter 25 in C. Gallindo-Leal and I. G. Câmara, eds. The Atlantic Forest of South America: biodiversity status, threats, and outlook. Washington, DC: Island Press.

Giraudo, A. R. and Povedano, H. (2003) Threats of extinction to flagship species in the Interior Atlantic Forest. Chapter 16 in C. Gallindo-Leal and I. G. Câmara, eds. The Atlantic Forest of South America: biodiversity status, threats, and outlook. Washington, DC: Island Press.

Hilton-Taylor, C. (compiler) (2000) 2000 IUCN Red List of threatened species. Gland, Switzerland: IUCN.

Hosmer, D. W. and Lemeshow, S. (1989) Applied logistic regression. New York: Wiley.

Lamas, I. R. and Santos, J. P. (2004) A Brazilian Merganser Mergus octosetaceus nest in a rock crevice, with reproductive notes. Cotinga 22: 38-41.

MMA (2003) Anexo à Instrução Normativa no. 3, de 27 de maio de 2003, do Ministério do Meio Ambiente. Lista das Espécies da Fauna Brasileira Ameaçadas de Extinção. Available at http://www.ibama.gov.br/fauna/downloads/lista \% 2ospp.pdf

Pacheco, J. F. and Fonseca, P. S. M. (1999) Evidência de ocorrência histórica do pato-mergulhão (Mergus octosetaceus) no estado do Rio de Janeiro. Atualidades Ornitológicas 88 (mar/abr): 10

Partridge, W. H. (1956) Notes on the Brazilian Merganser in Argentina. The Auk 73: 473-488.

Pineschi, R. B. and Yamashita, C. (1999) Occurrence, census and conservation of the Brazilian Merganser (Mergus octosetaceus) in Brazil with notes about feeding behaviour and habitat preferences. Monterrey: Proc. Neotropical Waterfowl Symposium, VI Neotropical Ornithology Congress, 7 October 1999.

Silveira, L. F. and Bartmann, W. D. (2001) Natural history and conservation of Brazilian Merganser Mergus octosetaceus at Serra da Canastra National Park, Minas Gerais, Brazil. Bird Conserv. Int. 11: 287-300.

Strahler, A. N. (1957) Quantitative analysis of watershed morphology. Trans. Am. Geophys. Union 38: 913-920.

Yamashita, C. and Valle, M. P. (1990) Ocorrência de duas aves raras no Brasil Central: Mergus octosetaceus e Tigrisoma fasciatum fasciatum. Ararajuba 1: 107-109.

Zar, J. H. (1984) Biostatistical analysis. Englewood Cliffs, NJ: Prentice-Hall.

IVANA REIS LAMAS

Instituto Terra Brasilis: Rua do Ouro 136/801, CEP 30220-ooo, Belo Horizonte, MG, Brazil; and Conservation International: Av. Getúlio Vargas 1300/7 $7^{\circ}$ andar, CEP 31112-021, Belo Horizonte, MG, Brazil.E-mail: i.lamas@conservation.org.br

Received 21 December 2004; revision accepted 7 July 2005 